UDC 821.161.1.09 Gogol' N. V.

https://doi.org/10.18485/ms zmskij.2020.68.1.4

Др Вук Петровић

\title{
ПОДЗЕМНИ ХУМОР ГОГОљЕВИХ МРТВИХ ДУША
}

Рад објашњава хумор као естетски принцип фигуралног слагања формално-материјалних нивоа текста. Симболичка фигурација подразумева естетско посредовање идеала, а хумор осликавање људске овостраности као подземно таворење у духовној удаљености од испуњавајућег смисла. Поетику хумора херменеутички утврђујемо на примеру Гогољевих Мрйвих дущиа као поетског космоса који је фигурисан укрштањем хуморескности основног плана текста и симболичког усмерења ка мистици душевног спасења. Чичоковљевска стварност поетизована је као хуморескна подземност људске огрезлости у мртвилу, коју пак посредно осветљава комичка путања поеме, те њено мистеријско испуњење у симболички сугерисаној неизрецивости човековог и руског приближавања божанском идеалу.

Кључне речи: хумор, симболика, фигурација, идеал, оскудност, подземност, комедија, мистика.

Као поетском тексту интенционално усмереном ка мистерији спасења, комедији је принципијелно својствен патос, а не хумор. Као драмска форма која се структурално и идејно усредсређује на остварљиву могућност срећног краја којим се (самоизопштена) јединка реинтегрише у сношљив поредак (FRYE 1979: 186ff), комедија се служи комичким техникама и средствима, али ове не треба поистовећивати с хумором. Заступљено као део поступка или грађе, комичко средство је тек јединица текстуалне целине, а ову као уметничку пак фундаментално одређује доминантни естетски принцип.

Комедија спасења - рецимо, дантеовска или фаустовска - по природи свог духовног тежишта не може бити заснована на пуким комичким елементима, будући да је њена доминанта са̂м есхатонски идеал, а овај се поетизује као симболичка трансфигурација човекове земаљске повести у вечност. Оптерећеност комедије значајним смислом (SCHILLER 1984: 259) приближава је патетичном регистру као узвишеној граничности човекове егзистенције и њених метафизичких консеквенци. На тако рећи сасвим супротном полу у односу на патос комедије спасења стоји комика, која управо релаксира 
текст, прочишћавајући га од патетичне граничности, а њу замењујући релативном безначајношћу човекових поправљивих грешака које мистеријску последичност човековог земаљског поступања сужавају на обичност самог земаљског живљења.

Док комедија спасења патетизује мистерију људске анабазе, хумор поетизује подземност човековог постојања. Хтонска хуморескност у оквиру мистеријске комедије карактеристична је у фази човекове привремене прикованости за дијаболично тле, дакле јунакове за свет Пакла код Дантеа, или Фаустове за Мефиста код Гетеа. Као поетску доминанту, хумор у самој драмској форми комедије примењује Аристофан. Штавише, фигуралност хуморескне подземности у његовим Жабама се и удословљава кроз неспретност Дионисове катабазе. Но, из чега се специфично састоји подземност хумора као естетског принципа?

Доминантни естетски принцип организује текст у формално-материјалну целину. Форма се транспонује на идеју, што значи да се значењски комплекс текста посредује поступком и начином. Док, примера ради, комика може бити елемент или форме (тј. појединачног поступка) или материје (тј. грађе), њу у активни део текстуалне целине преображава тек естетски принцип. Највреднији принципи актуализују највише могућности како форме, тако и садржине и значења по себи, те их у врхунским случајевима синтетизују у саму естетску фигурацију идеала као уметнички остварене идеје.

Ако фигурацију разумемо као уметничко слагање форме и материје, односно као естетску, чулно-сликовиту и језичку израженост смисла, онда је вредносно најповлашћенија фигурација - симболичка естетизација метафизичког смисла. Књижевно значење идеала подразумева управо естетску посредованост идеје као највише амплитуде човекове духовне активности. Хумор објашњавамо као човеково егзистенцијално таворење у иманенцији која оскудева у идеалу, но чија сама оскудност фундаментално утиче на значење и квалитет овостраног постојања. Овако схваћена оскудност врло се разликује од деидеализованог прозног света натурализма у којем идеал или његова одсутност не представљају никакву чињеницу. Натуралистичка деидеализација, рецимо флоберовског типа, формира значење на основу миметичке референцијалности, а ова зауздава текст у материјалној и позитивној једнослојности: позитивне датости текста одговарају позитивној амплитуди значења. Хуморескна оскудност човековог света се, с друге стране, фигурише као укрштање позитивних и идеалних нивоа значења, при чему је позитивна датост приказаног света симболички поетизована и мотивисана релацијом (какве у флоберовском натурализму нема) - према оном идеалу у коме се оскудева (на пример, код Аристофана је то есхиловски идеал херојске прошлости).

Прозни свет функционише као систем датости, а хуморескни свет постоји као поетски космос релације између сфере датости као иманенције и апсолутне равни идеала. Симболичку укрштеност реалитета и идеалитета као објективних координата поетског космоса - хумор конкретизује пре- 
наглашеним усредсређењем на овостраност као оскудно огледало удаљеног идеала. Како смо историју размишљања о хумору као поетској категорији утврђивали на другим местима (Петровић 2013; 2018: 93-112; Petrović 2018: 79-85), сада издвајамо њена идеалистичка тежишта (ослањамо се понајвише на Золгерове и Хегелове мисли) која хумор објашњавају, опште узев - као судар неједнаких и узајамно неодговарајућих величина, а, конкретније, као трапаву збиљу додира између идеала и стварности из перспективе саме ограничене и уске стварности.

Сходно томе, земаљско оскудевање у апсолутном идеалу може бити узроковано помућеношћу самог човечанског погледања у идеал чији се смисао, услед човекових епистемолошких граница, или сасвим превиђа или се рђаво тумачи. У том случају хумор се остварује као динамичка повест људске дезоријентисаности у земаљској стварности чија непоправљивост и, евентуално, безнадежност - произлазе из неумољиве трансцендентности идеала. Овај не постоји како би еманирао своје потенције на иманенцију, већ како би, напротив, својом недокучивошћу вратио земаљској сфери њену немоћ и маленкост, с обзиром на коју човеков живот поприма форму бесциљног лутања у духовној тами. Такву форму остварује Кафка у романима, чији је екстремни песимизам узрокован не пуком узалудношћу „јунакових“ радњи, него превасходно апсолутним идејним амплитудама те узалудности, а због којих укупна његова судбина постаје хуморизована историја максималне удаљености од по себи постојеће истине (независно од тога да је она афирмативна или не). Објективност смисаоног одсуства из човекове овостраности може се, с друге стране, надоместити ексцентричношћу људског труда као субјективним источником ишчезлог идеала. Дон-Кихотова судбина пример је хуморескне непомирљивости и, управо, трапавости контакта између деидеализоване стварности прозе и човекове индивидуалне жеђи за идеалом који се, онда, насилно и на неодговарајуће начине намеће реалности која је пак за идеале постала непропусна.

Још један могући правац хуморескне поетизације - при чему је чест случај да аутор постигне фигурисаност свих значењских потенција хуморескних релација, али је једна од њих идејно и уметнички повлашћена односио би се на објективну извесност и сигурност (којих код Кафке нема) апсолутног идеала који се, међутим, услед људске субјективне оскудице потпуно промашује и превиђа. Следствено томе, човеков живот претвара се у несвесно добровољно таворење у обездуховљеном материјалитету и подземну заробљеност у дехуманизованој празнини бесмисленог животарења. Парадигму овакве поетске ситуације представљају Мрйве дуще , а образложење хумора као уметничког начела Гогољеве „поеме“ основни је задатак нашег рада.

У складу са уједно „земним“ и „подземним“ значењем грчке речи $\chi \theta \omega ́ v$, разуме се да хуморескну подземност разумевамо квалитативно, а не топографски. Подземност је духовна последица човекове претеране или искључиве усредсређености на материјалност, односно тварне равни постојања. 
Реч је, дакле, о својеврсном начину на који човек тумачи стварност, а у којем се пак огледа не толико објективитет спољашњости по себи, колико унутрашња вредност самог тумача. Сводећи егзистенцију на спољашње, тварне манифестације, човек промашује властиту есенцију, па - консеквентно томе - престаје да буде хумани субјект смисла. Уместо живљења као стварања сопственог и увиђања светског значења, „хтонски“ човек срозава се на унутрашњу обездуховљеност, етичку и естетску оскудност. Како није и не може бити племенито стваралачка, његова активност негативно се реализује као саучествовање у материјалистичкој деградацији света и човека на дијаболично апсурдну хаотичност. На овако описаним координатама заснован је свет прве књиге Мрӥвих дущиа.

Херменеутички је значајна интендирана вишетомност овог дела које са̂м аутор формално одређује као поему (нпр. Гоголь 2009: 19, 71), и то руску (Исто: 186). Наиме, фрагменти друге књиге Мриивих дущи арагоцени су као посредна потврда подземне природе хумора: док је хуморескна доминанта у првом тому нераскидиво повезана с уметничким фокусом на најнижој тачки људског пада, предвиђено путовање душе од проклетства ка могућем преумљењу у другом тому нужно мења са̂м поијетички модус и изражајни регистар, сходно чему хумор уступа пред дигнитетом приповедачеве заинтересованости за човеково етичко поправљање.

Поема уобличава свет који је поетског, а не прозног квалитета, при чему је значењска амплитуда самог поетског света Мрӣвих дущua - космичка. Поетски космос Гогољеве поеме фигурише се мистеријски, и то кроз познату аналогију према Дантеовој Комедији као комедији спасења, ${ }^{1}$ при чему се најважнија потврда стварних и свесних веза Гогољевог текста с Комедијом налази у самој поеми, у којој је чиновниково спровођење Чичикова кроз просторије суда упоређено с „некадашњим Вергилијевим служењем Дантеу“ (Исто: 147).

Аналогије се тичу формалних граница светова, које у оба случаја имају космички домет, али такође и идеала као тежишта космоса. Људска повест поетизује се као космичка драма, а њена метафизичка - код Дантеа и експлицитно есхатонска - суштина фигурише се кроз човекову индивидуалну повест као конкретну тачку преламања космичких дејстава. Будући, према томе, поијетичке и везане за са̂м уметнички поступак и став према квалитету значења, аналогије између Комедије и Мрихвих дущи нипошто нису садржинске у ужем смислу, јер би такво Гогољево успостављање веза с Дантеовим текстом водило алегоризацији као симплификацији фигурално оствариваног идеала.

Штавише, посреди би била двострука алегоризација као пука маниристичка парафраза у унапред утврђеном и познатом значењском кључу - прво-

${ }^{1}$ О томе се говори у: Тоичкина 2009: 130-139; Фомичев 2009: 430-446 (ови аутори наглашавају и важан утицај Енеиде Котљаревског на Гогоља); МАнн 1978: 340-341. Узгред, указујемо и на радове који скрећу пажњу на аристофановске елементе Гогољеве уметности: МАнН 1978: 203; КАРТАШовА 2009: 86-96. 
битне и утолико аутентичне Дантеове алегорије. Ако алегорију одредимо као настојање да се уметничком представом илуструје општа идеја, онда алегоријски принцип Комедије твори како сама поетизација теолошког, схоластичког комплекса идеја, тако и конкретно огледање есхатонских процеса космоса у посебној драми људске душе. Поетску веродостојност Дантеовој алегорији обезбеђује пак сама фигурисаност неуметничке идеје у уметничком идеалу међуљудске љубави као одсјаја и потврде божанских закона света.

Дантеову алегоријску фигурисаност томистичког учења као начин на који је идеја уопште транспонована поетском формом - Гогољ уметнички усложњава симболичком фигурисаношћу унутрашњих слојева самог поетског света Мрйвих дущи (а не, као код Дантеа, алегоријским посредовањем екстратекстуалног духовног наслеђа). Алегоријска илустративност дантеовске мисли која се поетски идеализује повешћу човекове душе замењује се код Гогоља симболичком пунозначношћу сваког текстуалног слоја чија аутономност собом значи релацију између материјалитета спољашњег приказа и идеалитета универзалног смисла. Овај потоњи није, наиме, алегоријски посредован предњим планом фабуле (Чичиковљевим смуцањима) као илустративним средством и поводом за остваривање позадинског значења, већ је са̂м универзални идеал текста фигурисан у Чичиковљевој повести. Једноставније речено: основна догађајност није алегоријска ознака нити пут за посебни комлекс значења, већ је, томе сасвим насупрот, та догађајност аутономни извор идеалног значења као сопственог. Оно има дантеовски - апсолутни и универзални домет, али је поетски конкретизовано гогољевским начином на који је идеал фигурисан самом фабулом. Тај начин јесте хумор као естетски принцип којим се спецификује симболички квалитет уметничког космоса.

Уместо алегоријског происхођења означеног смисла из приказа као означитеља, Гогољев поетски свет заснован је на удословљавању предњим планом фабуле развијане фигуре „мрвих душа“. Гогољева уметничка путања у том смислу не само да мења срж дантеовске фигурације, него и потпуно изокреће њено алегоријско усмерење. Док је основно значење синтагме „мртве душе“" трополошко, Гогољ разара њен очекивани и то, превасходно, алегоријски капацитет, тако што најпре алегорију претвара у дословност, те потом и тако што удословљеност поетизује као фигуралност чије се семантичке могућности, захваљујући обрту, проширују у односу на ограниченост алегоријског тумачења мртвих душа.

Трополошки квалитет „мртвих душа“ происходи из чињенице да је алегорија душе усложњена - оксимороном. ${ }^{2}$ Синтагму је могуће разумети као contradictio in adjecto тек на фону поимања душе као хришћанске (или

${ }^{2}$ Развијајући тезу о реалистичкој гротескности Мрйвих дущua, Гинтер инсистира на Гогољевом остваривању гротеске кроз стил и склоност ка изражајним противречностима (GÜNTHER 1968: 194-198). 
шире узев: као идеалне) алегорије. Човекова душа је, према томе, непропадљива есенција која само једну фазу своје динамичке вечности живи у материјалним оквирима, односно на земљи и унутар човековог пропадљивог тела. Душа је огледало вечности у човековој смртности, те она суштина која смртника, након његове земаљске пропасти, прикључује метафизичком поретку космоса. Гогољ, међутим, не твори упрошћену инверзију, која би подразумевала смртност или умирање душе: строго узев, изокретање душе као идеала (а насупрот телу као материји) значило би третирање душе као времените категорије. Уместо да, дакле, додели души смртност и пролазност, Гогољ је фигурише као симбол саме смрти у оквиру овостраног живота, чиме кардинално мења идеални смисао душе као огледала вечности (такође, у оквиру земаљског живота). Како тело пак и даље умире, тако се душа испоставља као есенција смрти пре њене физичке експликације. Но, она то, наравно, није и не означава по себи, већ само у контексту смисаоне целине прве књиге Мрйвих дущua, која је заснована на принципу хуморескног одступања у начелу, а што се саме синтагме тиче - одступања од питагорејско-платонско-хришћанском традицијом стабилизованог значења душе као бесмртног антипода смртног тела.

Док вечност представља хуманистички идеал већ и утолико што је њена апстрактност конкретизована кроз категорију живота, па се тако смисаоно испуњава као вечни живот, свет Мрйвих дущиа поетизован је као перманентна сенка смрти. Још један парадоксални обрт огледа се у томе што je, традиционално, пропадљиво тело знак смртности, а што је код Гогоља пак душа огледало самог тела. ${ }^{3}$ Наиме, не само да се - на равни реалитета описаног света у првој књизи - не прати квалитативна дистинкција између провизорности тела и аутентичне вредности душе, него се ове две категорије постављају у хармонију по негативном принципу, при чему хумор извире управо из њега. Гогољевска душа је огледало смрти, зато што је сасвим изгубила своју суштину која би је, иначе, или вредносно разликовала од тела, или би се пренела на телесну спољашњост као лепу физичку манифестацију унутрашње, душевне изврсности. Као испражњена од људског значења и потпуно оскудна у садржају својственом људској нутрини, душа губи дистинктивни квалитет у односу на тело, те постаје пука химера, а суштинско сведочанство човекове обездушености и његове самосведености на ништавност тела које у себи не носи ништа. Оваква ситуација је конкретизована фабуларним парадоксом који се тиче третирања душе као материјалног феномена који доприноси купчевој социјалној позицији. Човек се смењује бројем (кметова које спахија поседује), а човеков живот смрћу, што

\footnotetext{
3 Основни слој гогољевске хуморизације значења потиче од изокретања платонскохришћанског дуализма душе и тела који има сасвим идеално тежиште. Допунски слој потицао би од травестије естетски конципираног архајско-класичног идентитета душе и тела, којим се тело увиђа као лепа манифестација и огледало душе (а не, као код Гогоља, душа као ружна екстензија човекове умртвљујуће самосведености на телесну спољашњост).
} 
од читавог текстуалног света твори својеврсну ентропију, дакле непрестану умртвљеност живих, чија надземна езгистенција онда и задобија подземни карактер.

Лишен, и то добровољно, своје људскости, а то значи - унутрашње смисаоности, човек постаје алогична случајност, чији живот представља низ произвољности. Сума таквих живота уметнички се изражава као систем хуморескних алогизама, ирационалних и апсурдних одступања, изокретања, изневеравања, и то посредованих како формом, тако и садржином. Но, гогољевски уметнички свет не исцрпљује се у оваквим координатама, већ њих поставља за хуморескни основ развијања идеала кроз умртвљеност чичиковљевске околине. Средишња категорија поеме је душа; као недосегнути идеал у прозној стварности она кореспондира с текстуалном формом која се из апсурдне алогичности описане догађајности уздиже до метафизичке комедије, а ова уметнички и смисаоно врхуни у питању спасења саме људске душе. То питање посредовано је целином очуваних делова Мрйвих дущu Чичиковом у другом делу поеме, у којем старац - „спаситељ“ (Гоголь 2009: 357) позива протагонисту да се одрекне материјализма, да се преусмери на пут доброте, те да уместо спасења иметка - уложи напоре да спасе душу (исто: 358-362). Муразовљеви искази драгоцени су и као трансцендентално огледало форме, путање и поступка саме поеме, будући да се ова из хуморескног одступања од смислене путање у првом делу - уздиже у потрагу за хумано спасоносним смером у фрагментима другог дела. Кључна поетска последица преусмерења самог текста јесте смена хуморескне доминанте у првом делу - дидактичком озбиљношћу другог дела. Наш циљ је анализа разлога из којих је подземност прве књиге подобна за хуморескно призивање идеала одсутног из чичиковљевског света, те из којих разлога текстуално приближавање извесном идеалу нужно преображава хумор у озбиљност и свечаност својствене патетичном регистру.

Премда су Мрйве дуще често жанровски одређиване као роман, ми инсистирамо на првостепеној важности многобројних трансценденталних самоодређења овог текста као поеме. То чинимо како бисмо истакли спрегу између форме и садржине, те уметничке последице њихових укрштања. Наиме, одредница „поема“ у складу је с йоейском формом Гогољевог текста. Насупрот прозној текстури као логички евидентној образованости значења, поетска творевина - за шта је Гогољево дело парадигматско - заснива се на иманентном процесу формирања аутентичног значења, које, према томе, не происходи из логичке интенционалности, него из изнутра генерисаних закона уметничког света. ${ }^{4}$ Ти закони су независни од рационалности прозног

4 „Али поетски говор [...] уопште не припада логичкој страни језика, већ музичкој; поезијом не може постати ништа што је усмерено ка знању и у њему има свој почетак“ исказ је којим Шлајермахер идеалистички и романтично утврђује суштину поетског језика (SCHLEIERMACHER 2018: 474), а који је у пуном сагласју с темељним претпоставкама готово 
структурирања (како синтаксе, тако и целине текста), а у случају Гогољеве поеме - сами одступају управо од прозне логичности, па се чак и развијају кроз њено изокретање. Но, упоредо с оваквом - хуморескном формативношћу, гогољевски свет своју поетску природу испуњава тек као комичка повест душевног спасења. Форма текста као анагошки усмереног пута омогућена је пак садржином, а ова је по свом карактеру прозна. Поема се, међутим, не исцрпљује у пуком контакту између садржине и значења, иначе би прозна материја генерисала прозни, односно - романескни (а не поетски) смисао. Сотериолошки смисао гогољевске поеме не образује се кроз спрегу с чичиковљевском садржином, него - напротив - кроз поетску фигурацију њене прозне сржи.

Основну материју текста чини фундаментално прозно оскудевање у духовном идеалу: лукачевски речено, чичиковљевски свет је прозаичност трансценденталног бескућништва (LuKÁch 1990: 49ff). Ипак, уметничка сложеност Гогољевог дела извире из чињенице да је ово шире од предњег плана основних - чичиковљевских и прозних датости. Проширење описане прозне духовне оскудности формално је поетско, а значењски је идеално. Врхунац поетско-идејне синтезе је најављена могућност спасења хуманог етоса у другом делу поеме, а његов темељ и главнина јесте хуморескна фигурација прозе и прозне материје у негативни одсјај човекове удаљености од идеала којем се пак текст постепено приближава и, приближавајући се, удаљава од хуморескног полазишта првог дела.

С друге стране, премда се поетичност форме остварује фигуралном надградњом прозне материје, самој природи гогољевске поетске форме у првом делу поеме сасвим одговара суштина садржинске прозе. Форма је поетизована хуморескно, што се најочигледније манифестује у њеној алогичној изатканости. Управо таквој - алогичној бити поетске форме адекватна је подземна срж садржине. Носиоци садржине су људске свести, а оне се преливају на опште стање света: хумана субјективност креира објективне принципе стварности. Гогољевска стварност је нередовна и хаотична, а таква је из разлога што је усклађена с мртвилом субјективности. Ова је, парадоксално, активна, али је делотворност те субјективности деструктивна и суманута, будући да не исходи из човека као субјекта целовитог живота, ума и достојанства који би властите вредности преносио на светску спољашњост, већ управо из човека као пуке спољашњости која рецидиве

свих нама познатих а истакнутих студија о Гогољу. У светлу наше тезе о иманетности прогресивног ширења поетског света Мрйвих дущua, значајна је и следећа Шлајермахерова мисао: „Поезија би, дакле, била једно проширење, ново стварање у језику, при којем се превазилази логички домен“ (Исто: 414). Главнина радова посвећених Гогољу подразумева ритмичку поетичност Гогољевог израза, те Гогољево дело као песничку прозу, па исцрпно елаборира песничке квалитете пишчевог уметничког дискурса. В. рецимо: ВиногрАдов 1926: 143ff; МАнН 1978: 277ff; ВиРОЛАЙНЕН 2011: 50-60; БЕлЫЙ 2011: 20ff, 295ff; GÜNTHER 1968: 191ff; ЕЈХенБАУм 1970: 245-263). 
сопствене нутрине транспонује на објективну стварност у виду хаоса. Утолико не само да је форма поеме у сагласју са садржином у начелном смислу него је, специфичније, форма објективног света прве књиге Мрйвих дущи адекватна ништавној суштини човекове субјективности.

Облик света првостепено је устројен хронотопом, а просторно-временски план текста је ирационалан, што значи да одступа од реалистичке миметичности. Он почива на правилима генерисаним поетском динамиком саме поеме. Та правила изокрећу или чак и поништавају емпирију и рационалне категорије. Објективитет простора и времена извире из начина на који гогољевски човек опажа, прима и поима како свет, тако и себе; своју умну јаловост тај човек надокнађује разиграним испољавањем свог унутрашњег хаоса. Ако - сходно аналогији према комици као елементу и хумору као естетском принципу - бесмисао разумемо као текстуалну јединицу, онда би њеној фигурисаности у уметнички приказ одговарао апсурд. Хумор је основни уметнички принцип сустицања малопре набројаних субјективних и објективних слојева поеме, а апсурд је конкретни резултат објективизације човековог безумља, те преношења самог бесмисла на опште законе и координате света, укључујући и простор и време.

Нередовност времена, његова хировитост, па и самовоља - уочљиви су, рецимо, у начину на који ради Коробочкин часовник: одбијајући предвидљиву извесност и пасивност своје функционалне сврхе, он избија по својој жељи (Гоголь 2009: 46), дакле у складу са својим - а посматрачима неразумљивим - законима. Ћудљивост времена, или, барем, временског апарата, мотивисана је нарочитим статусом човекове свести. Супротно очекиваном, она не хаје за разложност, али се такође и не пита о одсуству разлога за појаве или о узроцима нередовних збивања, сходно чему их суштински и допушта и оправдава. Незаинтересована за смисао или мањак смисла, мртва нутрина, односно мртва душа - изазива преокретање укупне стварности, с обзиром на шта постаје могуће да душа као есенција људскости живота постоји као мртва, а да пуки инструмент задобије сопствени живот и вољу. Још један пример за атипични статус времена у поеми - и сложенији већ и утолико што је везан за начин на који ликови говоре и тиме изговарају и разокривају себе - јесте склоност беседника да приповеда о „покојницима“. Трудећи се да угоди госту, тако што му нуди да га почеше по петама, Коробочка сулудост своје понуде правда речима да је и њен „покојник“ то волео (Гоголь 2009: 47). Необичност исказа узрокована је својеврсним бркањем и хаотичним стапањем прошлости и садашњости као ондашњице покојниковог живота и садашњице његове преминулости. Не ради се, наиме, о томе да спахиница сетно евоцира прошлост у којој је субјект говора (њен муж) живео, већ о томе да инсистира на именовању тада живог субјекта - као покојника. Оживљавајући његову прошлост, она га парадоксално умртвљује као живог, и то тако што експресивно укида границу између времена живота и смрти. Реч је о нарочитом доживљају света: спахије поимају и време и човека хтонски, као наличја смрти, осведочавајући тиме склоност како ка 
оживљавању смрти (отуд покојник постаје наративна константа, независно од времена о којем се и у којем се говори), тако и ка умртвљењу живота, говорник престаје да разликује живот и смрт, а са̂м постаје, попут Пљушкина, слика смрти, или, попут Собакевича, „тело у којем, чини се, уопште није било душе“; Исто: 102). Коробочкин ноћни долазак у град, који је узроковао Чичиковљев пад и разоткривање његових послова, описан је као уплив ноћне сабласти у њој туђи свет људи. Иако са̂м живо ништавило, Собакевич оживљава смрт, третирајући своје умрле сељаке као живе и удахњујући им карактер и прошлост: Коробочка претвара живот у окамењено покојништво, а Собакевич уноси смрт у садашњицу живих. Покушавајући да се утеши услед тога што му је погребна поворка за тужиоца препречила пут, Чичиков се - супротно очекиваној лог̄uщи народног сујеверја - досетио како је „кажу, срећа ако сретнеш покојника“ (Исто: 225). Премда протагониста говори о мртвом тужиоцу као напросто покојном, његов апурдни исказ наводимо због тога што је подстакнут тужиочевим ликом, а опис његове смрти до пароксизма је довео општу поетску тежњу за укрштањем времена живота и смрти: тек је његова смрт разоткрила да је тужилац ипак имао душу, додуше толико умртвљену да га је само размишљање (дакле, душевно-духовна активност) о смислу Чичиковљеве куповине мртвих душа - убило (Исто: 214-215).

Категорија поетског простора многослојно је онеобичена. Општа фигурисаност текста као одступања просторно се конкретизује као скретање. ${ }^{5}$ Бизарност Чичиковљевог пута састоји се из случајности његових набасавања на спахије као исхода преумеравања с циља: рецимо, протагониста жели да посети Собакевича одмах након Мањилова, али идући ка њему Чичиков стиже најпре Коробочки, па затим Ноздрјову. Форма телеолошког хода преображава се у путописну травестију као повест о јунаку којем се, упркос томе што он има и вољу и циљ, путовање збива, уместо да га он ствара. Као што је време повезано с ентропијском доживљајношћу ликова, тако и преусмеравање и Чичиковљево скретање с просторног плана стоји у спрези с начином на који приповедач развија текстуру своје приповести: он је склон тематским скретањима и одступањима од основне или барем најављене приче. $^{6}$

С обзиром на комичку тему поеме, немогућност правог пута има и дословни и фигурални смисао јунакове неспособности да испрати постојећу телеолошку путању Мрйвих ду쓰, услед чега се са̂м текст успорено уздиже над хаотичношћу првог дела коју узрокују и приповедач, који одрећује форму,

\footnotetext{
${ }^{5}$ О поетици простора у Гогољевом делу детаљно и свеобухватно говори Лотман (1993: 263-313).

${ }^{6}$ Примери су бројни; рецимо, друга глава се отвара приповедачевим наглашавањем потребе да се скрене с основног тока приче како би се извршила карактеризација Петрушке и Селифана; ово преусмерење завршава пак у новом склизнућу, будући да се накнадно одустаје од обећаног описа Селифана.
} 
и ликови, који чине садржину. Та немогућност даље се поетски објективизује као ирационалност и алогичност простора попут Собакевичевог села: оно је тако рећи реализовано одступање од било каквог архитектонског и композиционог реда. Ако нередовност времена надограђује Коробочкину субјективну одусталост од смисленог примања живота, онда асиметричност Собакевичевог простора креативно објективизује изворно одсуство смисла у нутрини творца тог простора.

Но, паралелно са самим својим хуморескним дејством, гогољевски простор активно учествује у фигуралном преображавању хтонско-хуморескног у комички квалитет поеме. Категорија текстуалног простора условљава поетску форму. Могућа духовна амплитуда форме објективизује се просторним границама: простор омеђава текстуалну стварност, а ова одреЂује протежност форме и њено заокруживање уметничког смисла. Темељно значење чичиковљевске стварности јесте сама нечовечна ништавност; међутим, поетска форма Мрйвих дущиа усмерена је ка трансцендирању овакве рђаве нискости, због чега поема непрестано твори пукотине које су, с једне стране, последица унутрашње несређености самог безвредног света, али су, с друге, путоказ за хумано освајање вишег смисла у односу на негативну стварност првог дела. Преусмеравање - овог пута ка вишим сферама духовног постојања - врши се кроз стварање дискрепанције између граница простора и значења. Наиме, максималној духовној ограничености одговарала би скученост простора. Хуморескно надрастање пуке сатире која би приказивала малограђанску ситничавост паланачког племства Гогољ пак спроводи проширујући простор провинцијске забити. У њој тавори духовна ограниченост, али је она сама гранична, а то значи да осцилира на прелазу из границе у безграничност.

Ноздрјовљев посед показатељ је отпорности на зауздавање: „Ето границе! - рече Ноздрјов. - Све што год видиш с ове стране, све је то моје, а чак и с оне стране, сва та шума, све што плави, и све иза шуме, све је то моје“ (Гоголь 2009: 76). Премда на статус ових речи утиче лажљиви карактер говорника, оне су принципијелно уланчане у магистрални уметнички поступак првог дела поеме, а реч је о фигуралном израстању метафизичке стварности из хуморескног темеља духовне оскудности. Проширење је поетско, зато што фигурално обогаћује сатиричко-критички капацитет приказане датости. Основни слој приказа је Ноздрјовљев лик као отелотворење безинтересне, игротворне лажи. Овај лик уметнички се усложњава најпре у себи самом, кроз непрестана ширења и измене претходно установљених карактеристика, с обзиром на шта се евентуална препознатљивост књижевног типа разлаже у атипичну ${ }^{7}$ хаотичност. Будући невероватна литерарна конструкција, Ноздрјов је хуморизован као динамички антипод приповедачевој евокацији узвишене истине ка којој текст стреми. Насупрот имплаузибилној

7 J. Ман посебно наглашава гогољевско разбијање традиционалног, класицистичког свођења јунака на типску карактеристику (МАнн 1978: 314-215). 
збиљи Ноздрјовљеве појаве стоји далека, али призивана и изрицана могућност човечне вредности. Њу непосредно зазива приповедачева жеђ за надрастањем описиваног света лажи и испразног зла, али је посредује и са̂м тај свет као несвесно и искривљено огледало далеког, но постојаног смисла. За говорника самог, исказ о граници је бесмислица, али Ноздрјовљева несвесност о значајном смислу бескраја хуморескно се укршта са свесним приповедачевим ширењем уског, ограниченог ноздрјовљевског света - бескрајношћу руског бића.

Форма Мрйвих дущиа је прогресивна у романтичном смислу те речи: као дело које динамички остварује своје идеално значење, при чему се перманентност духовног раста текста уметничким обликом заокружује у бескрај као само значење. Константа Гогољеве поеме је изливање из претходно стабилизованих координата форме: време пролазности излива се у вечност, а простор етичких и епистемолошких ограничења израста у бескрајност. Чичиков промашује путеве због начелне зачараности света у неразумности, због сопствене ирационално опсесивне и заслепљене заробљености у нечасном циљу који је у свом хтонском материјализму максимално удаљен од било каквог идеала, али такође и због Коробочкине неспособности да прецизира позицију правог пута (,Запетљано је то рећи, има много кривина“; Гоголь 2009: 59) или Собакевичевог одбијања да се уопште изјасни о путу (до Пљушкина).

Неразумни и безразложни назори и поступања спахија у складу су с ирационалном и фантастичном збрканошћу њихове стварности. Ова се, што је парадоксално, историјски манифестује као материјални реалитет руске државе, као Россия, над којом се пак уздиже хиперисторијски идеал Русије као највише остварљивости људских моћи - то је Русь. ${ }^{8}$ Потоња постоји као вечност трансматеријалног огледала у земаљској стварности. Као поетски принцип текстуалне целине и модус изражавања значења, гогољевски хумор се реализује као судар две стварности, материјално-историјске, тј. чичиковљевске и идеалне. Стварност руског идеала симболички је експлицирана птицом-тројком у финалу првог дела поеме, а њена симболичка вредност састоји се из двострукости: њеног израстања из иманенције и људског тла (то је руска држава) и уливања у метафизичко-есхатонску апсолутност која искупљује човека као таквог и која се, према томе, више не тиче уских етничких и историјских одредница, већ хуманости и хумане повезаности са мистиком божанске вечности.

Хуморескно фигурисање симболички посредованог идеала из подземне суштине људске беде и негације живота - поетски се врши и квалитетом израза. Специфичност модуса којим се исказује пука грађа смисаодавно уобличава садржину у уметничку вредност. Једна таква специфичност је апофатичко одређивање предмета говора. Апофатичка традиција је, разуме

${ }^{8}$ О универзалности руске теме у Гогољевој поеми видети у: Кривонос 2011: 483-494; Гуковский 1959: 206ff; МАнн 1978: 277ff; LotмAN 1993: 300-313. 
ce, теолошка и, као таква, она представља начин на који се може језички и изражајно приступити пуноћи божанске апсолутности. Апофатика синтетизује трансценденталност као човекову духовну и, конкретно, експресивну моћ са трансценденцијом као највишим и искључивим предметом израза. Гогољ поетски модификује узвишено усмерење апофатичке теологије, и то најпре тако што хуморескно изокреће вредност њеног метафизичког тежишта, а потом и тако што остварену хуморескну изокренутост поставља за полазиште приближавања идеалу.

Гогољ чува форму, а преокреће суштину негације као једине одговаpajyће мере човековог разматрања необухватљиве и неизрециве божанствености. Уместо да се негацијом сугерише истовременост немоћи и посредне могућности било каквог човековог приступања апсолутној, недосежној вредности, она у Мрӣвим дущама постаје изражајно сведочанство самог негативног света. Наиме, Бог „није“ за самог човека и перспективу његове маленкости, а чичиковљевски свет „није“ по себи, услед чега се негативитет такве збиље посредује негативним исказима. Садржина одсуства и мањка поетизована је апофатичком формом израза. Позитивна сфера текстуалних датости (материјалне стварности руског друштва) парадоксално постоји као негација - бића, човека и живота. Међутим, материјалистички свет духовне и животне оскудности није апсолутно негативан, већ је - а у томе се и налази кључ гогољевског смисла - негативитет хуморескно релативизован према постојаности онога у чему се оскудева.

Свет небића је фигурисан као паклена подземност, односно као сфера која суштински мимоилази живот, па се стога закључава у сопственој јаловости. Овостраност се приказује као симулација живота из које изостаје сама супстанца племените човечности, но у којој се и даље - а отуд извире хумор - упорно истрајава, с обзиром на шта се живот претвара у своју сенку. Чичиков „није ни лепотан ни ружне спољашњости; ни одвећ дебео ни одвећ мршав; не може се рећи ни да је стар, а исто тако ни да је превише млад“ (Гоголь 2009: 7) - као гогољевско лице без својстава, он представља привид саме људскости, постојање које је лишено индивидуалних одредница. Као умртвљена сенка личности, провинцијски племић попут губернатора са̂м је: „како се испоставило, налик Чичикову, ни дебео ни мршав“ (исто: 12). Уз то, Чичиковљево бивствовање сугерише само странствовање у људском животу: као дете није личио на родитеље; неугасивост његовог животног труда за стицањем материјалног иметка претворила се у неприродност - као да је „то био ђаво, а не човек“ (исто: 241). Аутоматизованост протагонистиног упорног срљања дијаболично се изопачује у негацију саме људске бити. За Мањилова се не може уопште рећи какав је: за разлику од човека као субјекта непоновљиве карактеристике, он „није имао ништа“ (исто: 25). Спољашња егзистенцијалност лишена хумане есенције лајтмотивски се наглашава приповедачевом немоћи да продре у нутрину ликова, што се пак хуморескно проширује могућношћу пробоја у мисли Чичико- 
вљевих коња. ${ }^{9}$ Пљушкин изазива изненађеност код градских моћника самим тим што уопште живи, Коробочка подозрење због своје ноћне сабласности, a Петрушка носи нарочит задах, дакле знак потеклости из хтонске сфере и странствовања у надземној равни живота, при чему се и за њега наглашава да се не може рећи шта је у себи мислио док га је господар критиковао. Слично лакеју, који је идентификован неживошћу ураслом у њега, Собакевич изгледа склепано, као неко око кога „природа није дуго мудровала“ (исто: 96): у извесној мери, његова појава је рецидив примордијалне хаотичности као претходнице реда, поретка и лепог облика индивидуалног човека. Собакевичевска аморфност небића или појаве која још увек није постала биће интензивира се у Пљушкиновом лику: Собакевич је тело без душе, а Пљушкин господар самог „изумрлог простора“ (Исто: 116) неживота, што је формулисано на апофатички начин: „Никако се не би могло рећи да је у тој соби становало живо створење“ (Исто: 117); трапава склепаност Собакевичева код Пљушкина се рефигурише као хаотична стопљеност и нерашчлањивост одумирућег тела и дроњака којима је оно одевено.

Но, Мањиловљева отпорност на било какво позитивно и - до чега је Гогољевом приповедачу веома стално - пластично, ликовно портретисање последица је такође и „крајње неухватљивости његових особина“ (Исто: 24). Иако је на плану основног значења приповедачева опаска о неухватљивости ствар како његовог ироничног карикирања Мањиловљеве људске неприметности, тако и начелне Гогољеве разградње једнослојне типичности ликова, само истицање човековог могућег трансекспресивног квалитета значајно је за укупно текстуално успостављање везе између људске величине, огромности и бескрајности руског пространства и идеалног проширења материјалне ускости рђавог света сфером неухватљиве и неизрециве вечности. Другим речима, карикатурални смисао апофатичког приступа свету немаштине хуморескно се проширује сугерисањем потенцијалне, но још увек неосвојене човекове духовне и живе неисказивости, и то помоћу Мањилова као тако рећи саме људске ништавности, да би се најзад хуморескна екстензија фигурално стопила с достојанственом озбиљношћу симболичког развијања чистог апофатички неизрецивог идеала спасоносне вечности на крају првог дела поеме.

Приповедачев уметнички идеал је питорескна јасноћа лика, могућност чистог естетског приказа. Насупрот пак призиваном идеалу живог ликовног уобличења стоји подземна стварност неживе беспризорности, односно немогућности да се пластично заокружи чиста и јасна људска форма. Чак се зачудна стварност нељудскости и посредује ликовним неукусом самих спахија. Док јасноћа узорне слике приказује живот смислене форме, ликовне „збирке“ спахија испољавају ишчезлост смисла из самог света, сходно чему,

${ }^{9}$ Слично томе, човекова неспосбност за аутоекспресију хуморескно се пренаглашава говором животиња: „[...] ћуран му је изненадно и веома брзо промрмљао нешто на свом чудном језику, вероватно „наздравље“, на шта га је Чичиков назвао глупаном“ (Гоголь 2009: 48). 
примера ради, код Пљушкина може да буде окачен на зиду „збркани“ (Исто: 117) низ приказа, међу којима и - обешена патка. Хуморескно исказана одсутност смисла, реда и лепоте из спахијске збиље узрокује приповедачеву жудњу за чулним оживотворењем вредне људске лепоте. До ње се пак поетски долази хуморизовањем неизрециве беде, која посредно мотивише чежњу за лепотом могућег идеала. Један од врхунаца екстензивног хуморескног ткања апсурда у односу на који се потом врши поетски скок ка симболичкој фигурацији идеала - остварен је и упечатљивим подземним дијалогом између „напросто пријатне“ и „, сваком погледу пријатне даме“. Представљајући сулудост и безумност јавног мњења, те трачарећи о позадини Чичиковљевих дела, њих две непрестано преусмеравају разговор са започете теме, а укупно пет пута (Исто: 186, 189, 191) своју или туђу реакцију на злокобну тајновитост Чичиковљевих превара именују „бледилом попут смрти“. Садржина разговора благо је хуморизована претерано неодмереним и инфантилним реаговањем на делимично разоткривене, а несхваћене сплетке протагонисте. Разговор је, међутим, хуморескно поетизован самом својом дијалектичком формом која одступа од смисленог тока, те која најзад исходи у преусмерењу разговора - ни у шта („но, на највеће чуђење, обе даме напрасно су се стишале и баш ништа није следило“; Исто: 190). Морбидност теме у сагласју је са самртничким бледилом посредника као тако рећи демона између живота и смрти, али поетско уобличење овакве, по себи суморне материје врши се кроз преусмерење са саме садржине на квалитет људске свести која ту суморност генерише: човечност је смењена смртоликошћу, људска тежња за разложношћу и умношћу повлачи се пред алогичношћу ништавила, а гроза нељудске стварности преображава се у смехотворност самог човековог скретања на „криви пут“ (Исто: 215).

Екстензивно скретање текстуалног тока у садржински бесмисао уобличава секвенце у апсурд: овај припада ликовима, али се симулира и приповедачевим хотимичним одустајањем од праћења магистралног фабуларног тока. Но, док свет неименованог градића остаје замрзнут у својој демонској сраслости са смрћу, бесмислом и ружноћом, као и у непоправљивости склизнућа из ништавности у ништавност, приповедачева свест узрокује квалитативна преусмерења као хуморескно премошћена искакања из сфере пакленог подземља људске тривијалности - у поље могућег људског оживотворења лепог смисла.

Поетски истакнут начин на који се припрема пробој у мистичке сфере апсолутног смисла јесте симулација хомерске компарације. Епска екстензија света помоћу поређења изискује патетичан и узвишен, херојски регистар који је по својим својствима сасвим удаљен од апсурдности антихеројског предњег плана првог тома поеме. Патос епског дискурса и значења код Хомера се постиже и поређењем као фигуралним проширењем основног плана епског приказа у људско-божански и природни тоталитет космоса. Како је овакав фигурални модус инадекватан самој материји Мрйвих дущиа, он се припрема и поетски мотивише стабилизацијом компарације као ширења 
бесмисла у апсурдну текстуру. Примера ради, приповест (која се, узгред буди речено, именује и као „поема“; Гоголь 2009: 204) управника поште о капетану Копејкину апсурдна је по себи и, као таква, она се хуморескно укршта с приповедачевим увођењем симбола птице-тројке у први план у наредној, последњој глави текста. Апсурдни карактер управникове приче узрокован је наметљивошћу њене немотивисаности, која - изван сваке плаузибилности - треба да насилно успостави везе обогаљеног Копејкина са загонетним Чичиковом (а преко тога и са одбеглим Наполеоном). Бесмисленост садржине одржава се и појачава интенционалношћу приче и контекстом који подразумевају жеђ слушалаца за причом независно од њене неодрживости. Са̂м управников говор максимализује хуморескност сказа већ и утолико што, упркос својој жељи за причањем, говорник стално скреће с теме и тешко се држи основног фокуса приче. У овакву позадину уметнуте приче уткана је управникова компарација златног и заводљивог Петрограда са - „бајковитом Шехерезадом“", „речју, Семирамидом“, „правом Персијом“ (Исто: 204-205). Апсурдност компарација, која је уметнички обезбеђена ширењем полазног елемента поређења на низ неједнаких категорија и разнородних величина, усклађена је с апсурдном суштином повести о Копејкину, као и њеном недовршеношћу, тачније наглом прекинутошћу. Компарација чува форму, а изневерава смисао епске компарације, при чему хумор извире управо из њихове инадекватности.

Недвосмислена хуморескност оваквог поређења усложњава се пак, на два места истакнутим, негативним поређењем деградиране садашњице с надмоћном прошлошћу: Собакевич носи „чизме толико дивовске величине, каквим тешко да се може наћи одговарајућа нога, нарочито у данашње време када већ и у Русији [на Руси] почињу да ишчезавају витезови“"(Исто: 17); хвалећи свог оца, а именујући га као покојника, Собакевич тврди како његове некадашње подвиге данас нико не би могао да спроведе у дело (,,[...] покојник је био знатно снажнији од мене [...] - не, данас више нема таквих људи“; Исто: 147). Аналогија с хомерским поступком почива на идеализованом времену прошлости: оно код Гогоља има псеудомитске црте које наглашавају ништавност, деидеализованост и дехероизованост садашњег доба прозне срозаности, а код самог Хомера успоставља аксиолошку норму митске стварности, у оквиру које садашњица представља деградацију идеалне митске прошлости. Карактер гогољевског подстицаја - то је у оба поменута случаја Собакевич као поредбени елемент - хотимично спутава патетично формирање идеала блиског хомерском митско-епском регистру. Међутим, са̂м процес хуморескне депатетизације (који је покренут управо Собакевичевим) омогућава зато формирање аутентичне гогољевске вредности која неће маниристички парафразирати и инадекватно у себе инкорпорирати патос епа, већ ће тај патос призвати како би га као далеки ехо данас одсутног људског херојства - саобразила специфичној смисаоној ступњевитости поеме. Хомерска компарација проширује амплитуде самог митског космоса, а гогољевска компарација фигурално проширује ускост 
фантастичног прозног реалитета бездушног подземља у поетски космос чија виша сфера живота постоји изнад саме чичиковљевске подземности која је у основном видокругу текста. Ефектни детаљи попут алузивних епских компарација трансформишу саму текстуалну стварност, прогресивно је уобличавајући у поему. Аутентичност трансформације сатире у поетски космос који допушта успостављање аналогија с хомерским или дантеовским регистром - мотивисана је хумором као модусом који евоцира идеал полазећи од признатог и исмејаног недостатка духовне вредности у људској стварности.

Премда су у Мриивим дущама алузије на хомерски епски модус очигледне, у раду смо пошли од разматрања веза с Дантеовом есхатолошким епом. Релације према оба регистра, хомерском и дантеовском, последица су јединствене Гогољеве уметничке тежње да сопствени текстуални свет фигурише хуморескним истицањем хумане и поијетичке парадигме кроз њено разабирање из сфера безумља. Узорни примери уметнички прослављене човечности артикулисани су у Хомеровом и Дантеовом тексту. Гогољева обавезност Дантеу је значајнија од алузија на хомерски еп, будући да код Хомера руски аутор препознаје превасходно узорну форму човекове узвишености, као и примерени уметнички поступак, али карактер самог гогољевског идеала фундаментално је хришћански и мистички, те је због тога по својој суштини кудикамо ближи Дантеу. Заправо, гогољевски космос синтетизује хомерски хтон као сферу неживота сенке без душе и дантеовску инферналну сферу човекове проклетости. Међутим, док је мистика спасења код Дантеа рационализована строгим композиционим ставом Комедије, као и њеном зависношћу од томистичког рационализма, проблематика човековог постојања, умирања и вечног живота код Гогоља задржава аутентичну мистичност захваљујући самој текстури поеме чија је иманентна логика отпорна на алегоријско упојмљење метафизичког значења.

Мистичка духовност може се поетизовати формом која апофатички изриче саму њену неизрецивост. Необухватљивост и несводљивост апсолутне тајне живота и бића уметнички се посредује сугестијом која, будући да уједињава израз и неизразивост предмета - јесте симболичка. Симболика гогољевске сугестије романтично је прогресивна због уметничког исказивања духовног обиља: поетска слика (рецимо, птице-тројке) самом својом лепотом објективизује узвишеност. Но, и до самог фигуралног преображаја лепоте естетске слике у мистику идеала долази се преко првостепене хуморескне фигурације бездушја у негативни одсјај и потенцију смисла. Ниска паралелизама формира сложену динамику смисаоног пута од изгубљености у апсурду, преко хуморескног скретања, до симболичког уздизања. Ланац фигуралних огледања конкретизован је степеновањем компарација: од апсурдне, која се замрзава у квазирелацији поредбених чланова (таква је компарација управника поште), преко хуморескне, која неспретно отвара нову сферу изврсности (човекове витешке прошлости), до оне поетски најважније, 
која са̂м руски идеал стапа најпре с птицом-тројком, а потом њу узноси у мистичку сферу божанске вечности.

Трансценденталним одступањем од усредсређености на фабулу, а у пуном духовном сагласју с немачком романтиком и њеним раније наведеним идеалистичким тумачењима хумора, гогољевски приповедач замишљен је над неопходношћу приказивања људског „талога“ (Гоголь 2009: 135), које је због своје „Узвишене, заносне“ смехотворности достојно лирског пева и равноправно с њим (Исто: 136). Апологија смеха, који ништавност материје фигурише у битност уметничког поступка и приказа, те који, дакле, самом својом поетичношћу надомешћује нискост прозаичне садржине, приповедачу је потребна како би се објаснило одсуство патоса из текста, но и како би се у поеми најавило - ,још увек далеко време [...] другачијег говора“ (Исто: 136-137). Хуморескна поетизација „кривог пута“ није сврха по себи, већ означава симболичко огледало - скретања са пута „вечне истине“ (Исто: 215), подземни одсјај „небеског пламена“, „небеског смисла“ (Исто: 216) чија светлост допире и до таме чичиковљевског света.

Живу потенцију једног таквог сјаја, симболичко уприсутњење вредне људскости у свету проклетости, те јемство за наду да људска изгубљеност није неопозива - представља лик златокосе лепотице, губернаторове кћери, чија је појава једина која је успела, додуше први пут тек привремено, да занесе Чичикова и одвоји га од спровођења фикс-идеје. Лепотица је, наиме, упоређена с „обрасцем за Мадону“ (Исто: 169). Док се хуморескна симболика „мртвих душа“ конкретизује оксиморонском конструкцијом, узвишена симболика девојчиног описа остварена је компарацијом са индивидуализованом парадигмом саме човечности.

Као текстуални елемент на овакав начин уведен у поему, Богородица се поетски уобличава с обзиром на Чичикова, као и с обзиром на приповедачев говор о птици-тројци на крају првог дела. Премда лепотичино поређење с Богородичином узорношћу припада приповедачу, а не протагонисти, лик губернаторове кћери принципијелно је преломљен из Чичиковљеве визуре. Ова је обојена управо неприродном и стога нечовечном упорношћу и тврдоглавошћу у целоживотном спровођењу рђавих настојања: Чичиковљева демонија извире из огромности његове улудо, бесмислено и погрешно усмерене снаге. Са̂м фанатизам труда, као и креативна бизарност досетке да се помоћу куповине мртвих душа материјализује труд - остављају пукотине за пробијање алогичности у Чичиковљевим подухватима. Једна таква пукотина је сама привременост његовог очовечења и оживљења у сусрету с лепотицом: демонски фанатизам безумног зла накратко се суспендује нехотичним бујањем Чичиковљевог осећања за људску лепоту. Попут тужиоца, само без стварних смртоносних последица, и Чичиков тек на трен разоткрива своју душу, чиме се посредно изоштрава бездушност његовог живљења пре и после тог трена. Поглед ка људској лепоти ипак оставља трајнији траг на његову нутрину, захваљујући накнадности девојчиног дејства на протагонисту: Чичиковљев пад у битноме је покренут на балу код 
губернатора, немарношћу његовог опхођења према дамама као последицом његовог другог сусрета с лепотицом.

Док чежња за девојчином лепотом осведочава пригушену, неискоришћену, но постојећу хуману потентност Чичиковљеву, најважнија пукотина у његовом демонском карактеру јесте сама релација између његове жеље да за собом остави потомство и готово страшљивог одбијања да купи женске мртве душе. Племенитост тежње за обезбеђењем потомства, којом се згоде с мртвим душама преображавају из ништавног циља у средство за вредни наум - ипак се ревалоризује самом својом прикованошћу за Чичиковљеву материјализацију човековог (умрлог) бића и његову банализацију мистерије смрти. А деградирани алтруизам хтења судара се с Чичиковљевим зазором пред било каквом живототворном релацијом према женама. Из протагонистине прошлости искључена је било каква емотивна упућеност на друго људско биће као такво, укључујући и жене, а његова садашњост оптерећена је преко сваке природне и разумске мере грешним пословима који се тичу смрти уместо живота - да евентуална висина жеље за децом узмиче пред нечовечном Чичиковљевом неспособношћу за искрено међуљудско искуство. Отуђеност од живе људскости хуморизује се управо демонском и хтонском присношћу Чичикова према купљеним душама које, наиме, назива „драги моји“ (Исто: 138), при чему - што је упечатљив пример хуморескног ширења текстуалног света путем поређења- замишља њихов могући бескрајни пев као Русија [Русь] што је бескрајна (Исто: 141). Пред Собакевичем апострофирана и необразложена одбојност према женским мртвим душама, као и потоње, такође необразложено, одбацивање подметнутих женских душа - знак су нередовне, демонске природе Чичикова. Нелагодност и подозривост пред женственошћу - живом или покојном - исходе из унутрашње Чичиковљеве хаотичности која у манијакалности свог слепила превиђа кардиналну разлику између живота и смрти, те саму женственост као есенцију људске животородности.

За Чичикова губернаторова кћер је заносна лепотица која разбуђује хуману потенцију у стварности демонског бића. Овакав сплет вредности и ништавности уобличава несређеност Чичиковљеве хуморизоване делатности као унутрашњу противречност између реалног и жељеног, средства и циља. Лик кћери се, међутим, сплиће и с узвишеним симболичким идеалом као исходиштем поеме: за целину текста, лепотица је реално пројављење узорне људскости и чистог и јасног индивидуалног лика. Текстуални идеал птице-тројке не представља пуку приповедачеву вербализацију која треба да квалитативно надогради подземну стварност текстуалног приказа, већ је идеал фигурално уткан у са̂м чичиковљевски свет. Опевање идеала на крају првог дела поеме експликација је објективизоване преломљености идеала у хуморизованом свету бездушности. Дакле, духовна и морална норма текста није само ствар приповедачеве субјективне надахнутости која би била у колизији с објективитетом исприповеданог, него је идеална норма најпре фигурално интегрисана у прозну садржину, а тек потом се и издваја 
као средиште приповедачевог пева. Ако је Марија симбол богородне човечности, индивидуализација људске моћи за стварањем вечности, онда човеково наликовање Богородици посредује овакву, узвишену лепоту стваралачког постојања, а девојчина сродност Мадони у оквирима света безумља - хуморизовано еманира постојаност узорне норме која се поетски укршта са смислом завршних речи првог дела Мрйвих дущuа.

Наиме, не треба губити из вида да лепотица није описана само као „образац за Мадону“, него као образац какав се „толико ретко среће у Русији [на Руси], у којој све воли да се покаже у широким мерама, све што постоји“ (Гоголь 2009: 169). Текстури „руске поеме“ припада лепота женственог савршенства које је пак другачије од норме руске прекомерности, огромности, изливања из граница. Посреди је суочавање две могуће норме - естетски савршеног реда и изливања из реда у бескрајност, при чему обе имају идеално, метафизичко исходиште у вечности, и поетски се сустичу и сједињавају у финалном фигурисању највише симболичке норме текста.

Ова потиче од преображаја Русије у „Русь“, те врхуни у апофатичком стапању „Руси“ с трансценденцијом: сила која вуче к руском идеалу је „недокучива, тајна“ (Исто: 226), моћ која узноси „Русь“ на небеса је „неспозната“ (Исто: 253), лет руске птице-тројке изражен је као „Божје чудо“, „У тим коњима неспознате светлости закључана је неспозната сила“, вертикални ход коња је „надахнут Богом“, а мистерија опеваног трансцендирања материјалне стварности „не даје одговора“ (Исто: 253) на низ приповедачевих питања. Несхватљивост људске подземности лајтмотивски се исказује кроз типове опаски које симулирају сказ, а најистакнутије су оне које евоцирају ђавола (управник полиције реагује на ланац Ноздрјовљевих незаустављивих лажи о Чичикову речима: „Само ђаво зна шта је ово“; Исто: 214) и Бога (,Можда би једино Бог могао да каже каква је личност Мањилова“, исто: 24; поводом тужиочеве смрти каже се: „О чему се покојник питао, због чега је умро, или због чега је живео, то само Бог зна“; Исто: 215). У оба случаја сама неразумљивост је последица одсуства унутрашњег смисла и разложних веза између појава, узрока и последица. Безумност човекове самоприкованости за материјалитет тла који се налази под њим једнака је ђаволској хаотичности која разбија смисао, а максимално је удаљена од надљудске несхватљивости божанске безграничности и бескрајности.

Слагање текстуалних нивоа гогољевског света и његовог уобличавања у космос врши се поетским принципима, а не наметањем садржинских веза. Консеквентно хуморескном ширењу духовног света из чулно представљене обездуховљености, мистеријско финале прве књиге фигурише се динамичношћу симболичког пута коња - од Чичиковљевих коња који унезверено беже из неименованог места, до птице-тројке која се узноси у апсолутност неописивог и неспознатљивог божанског идеала. Истичемо важност чињенице да је приповедачева химна духовној узвишености подстакнута стварношћу неславног и поражавајућег Чичиковљевог бекства: химнички дискурс генерише се, према томе, њему сасвим инадекватним, а по себи суморно 
хуморескним приповедањем о губитничкој прозаичности протагонистиног повлачења. Изражајно-смисаони скок од реалне прозаичности до идеалне поетичности мотивисан је стварношћу Чичиковљеве изгубљености на руској земљи. Та земља има своје реалне и материјалне координате које, по временитости историјских збивања, одговарају слепилу човекове физичке погнутости ка материјалитету постојања. Но, упоредо с тим, земља има - или може имати - духовну амплитуду израстања узвишеног, значајног смисла из саме материје. Ништавност твари која окружује гогољевске сподобе ништавна је само за њихов уски поглед, а по себи је извориште идеалних потенција, поље које разоткрива несхватљивост онога што се налази изнад човека (који се, загледан у твар под собом, у мртве душе, тако и превара у људску сенку).

Као врхунац поеме, трансцендентно обиље није статичка конструкција приповедачеве усхићене запитаности, него је исход динамичке трансфигурације недостојног, чулног и нечовечног у узвишено. Ова је доследно поетски извршена најпре хуморескним фигурисањем апсолутног идеала кроз преламање подземних последица његовог одсуства, те потом и симболички, фигурисањем „Божјег чуда“ из сликовите уприсутњености Чичиковљевих коња који се, газећи по материјалитету руске земље, транспонују на птицу-тројку која узлеће са смехотворности тог тла ка идеалним сферама. Оне су саме невидљиве из перспективе заслепљеног човека, па су утолико суштински и изгнане из људске земне стварности, но ипак су у њој као потенције пројављене. У неразумевању узорне девојчине лепоте хуморескно се огледа духовна оскудност спахија, али сама узорност те лепоте симболички сугерише властити идеални извор, а ка њему хита птица-тројка напуштајући хуморескну бит свог полазишта и допуштајући приповедачу да оствари и да у другој књизи настави да испуњава потребу за „величанственом грмљавином другачијег говора““ (Гоголь 2009: 136-7).

На почетку рада наведено приповедачево поређење Чичиковљевог хода кроз суд с Дантеовим слеђењем Вергилија - хуморескно је у произвољности своје асоцијативне непримерености, која се тиче различитих регистара двају текстова: патос Дантеовог епа брани се стварним дигнитетом јунака и његовог духовног водича, а достојанство код Гогоља постоји као приповедачева жеља за смислом потекла од његовог гледања људског пада. Но, поређење је уједно хуморескно и у произвођењу истине из нестабилног темеља инадекватности. Наиме, ширење поеме и њено динамичко уобличавање у космос заснован на идеалној норми - посредно оправдава дубљи духовни домет саме приповедачеве опаске.

Људско проклетство у Паклу патетично је како због есхатонске вечности сфере којој припада, тако и због етичке узорности Вергилијеве фигуре. Стварна пак проклетост у првом тому Гогољеве поеме условљена је баш недостатком вергилијанског вођства, услед чега се празнина попуњава хуморескним евоцирањем достојног смисла кроз недостојност поређења римског песника са судским чиновником. Аутоматизована бирократизованост 
обездушеног света, у чијем хаотичном формирању учествују и чиновник и Чичиков, слика је ништавног зла чије се инферналне метафизичке консеквенце, што је парадоксално, адекватно поетизују управо инадекватношћу хуморескног фигурисања идеала спасења кроз збиљу проклетости.

\section{ИЗВОРИ И ЦИТИРАНА ЛИТЕРАТУРА}

Белый, Андрей. Мастерство Гоголя. Москва: Книжный Клуб Книговек, 2011.

Виноградов, Виктор. Этюды о стиле Гоголя. Ленинград: Асаdemia, 1926.

ВиролАйнен, М. Н. Проза Гоголя как поэзия. М. Н. Виролайнен, А. А. Карпов (ур.).

Феномен Гоголя. Санкт-Петербург: Петрополис, 2011, 50-59.

Гоголь, Николай Васильевич. Собрание сочинений. Том 3. Москва: Время, 2009.

Гуковский, Г. А. Реализм Гоголя. Москва, Ленинград: Государственное издательство художественной литературы, 1959.

ЕЈхенБАум, Борис. Како је написан Гогољев „Шињел“. Лейойис Майиие срӣске 143/5 (1967): 398-413.

КАРТАшовА, И. В. Традиции романтической иронии в прозе В. В. Гоголя 1830 -х годов.

М. Н. Виролайнен, А. А. Карпов (ур.). Феномен Гоголя. Санкт-Петербург: Петрополис, 2011, 86-95.

Кривонос, В. Ш. Символическое пространство в „Мертвых душах” Гоголя. М. Н.

Виролайнен, А. А. Карпов (ур.). Феномен Гоголя. Санкт-Петербург: Петрополис, 2011, 483-493.

МАнн, Юрий. Поэтика Гоголя. Москва: Художественная литература, 1978.

Петровић, Вук. Шарени одсјај: немачка романииична йоеиика симбола и Геиееов Фаусти. Београд: Филолошки факултет, 2018.

ПЕтровић, Вук. Увод у проучавање хумора код Кафке. Кюижкевна исйорија 149 (2013): $95-119$.

ТоичкинА, А. В. Тема ада у Котляревского и Гоголя (,Энеида” и „Вечера на хуторе близ Диканькы”). М. Н. Виролайнен, А. А. Карпов (ур.). Феномен Гоголя. Санкт-Петербург: Петрополис, 2011, 130-138.

Фомичев, С. А. „Мертвые души”: инерция замысла и динамика откровений. М. Н. Виролайнен, А. А. Карпов (ур.). Феномен Гоголя. Санкт-Петербург: Петрополис, 2011, 130-138.

Frye, Norhrop. Anatomija kritike. Zagreb: Naprijed, 1979.

Günther, Hans. Das Groteske bei N. V. Gogol. München: Verlag Otto Segner, 1968.

Lotman, Jurij. Umetnički svet u Gogoljevoj prozi. Treći program Radio Beograda 96-99 (1993): 263-313.

LuKÁch, Georg. Teorija romana. Sarajevo: Veselin Masleša, Svjetlost, 1990.

Petrović, Vuk. Skica istorije poetskih modusa. Folia linguistica et litteraria 25 (2018): 49-86. 
SCHILLER, Friedrich. Über naive und sentimentalische Dichtung. Über das Schöne und die Kunst. München: DTV Verlag, 1984.

SCHLEIERMACHER, Friedrich Daniel Ernst. Ästhetik / Über den Begriff der Kunst. Hamburg: Felix Meiner Verlag, 2018.

Vuk Petrović

CHTHONIC HUMOUR IN GOGOL'S DEAD SOULS

Sum mary

The paper elucidates the idea of humour and expounds it as an aesthetic principle used for harmonizing formal and material levels of the texts. The symbolic figuration includes aesthetic portrayal of ideals, whereas humour incorporates the depiction of human earthliness presented as the chthonic lingering whilst spiritually drifting away from the fulfilling purpose. The poetics of humour is hermeneutically asserted through the illustration of Gogol's Dead Souls. This novel is figurated through the intertwining synthesis of the humour of the basic outline of the text and the symbolic inclination towards the mystique endowing the idea of soul salvation. Chichikov's world is poetized as a satirical delineation of human's irredeemable lifelessness, which is indirectly enlivened by the comic character of the poem and its transcendental realization through the ineffable yet symbolically implied inability of one to approach the divine ideal.

Универзитет у Београду

Филолошки факултет

vuk.petrovic@fil.bg.ac.rs 